\title{
Article \\ Coupling High-Resolution Numerical Weather Prediction and Computational Fluid Dynamics: Auckland Harbour Case Study
}

\author{
Amir Ali Safaei Pirooz ${ }^{1, *}$, Stuart Moore ${ }^{1}{ }^{\mathbb{D}}$, Richard Turner ${ }^{1}$ and Richard G. J. Flay ${ }^{2}$ \\ 1 Meteorology and Remote Sensing, NIWA, Wellington 6021, New Zealand; stuart.moore@niwa.co.nz (S.M.); \\ richard.turner@niwa.co.nz (R.T.) \\ 2 Department of Mechanical Engineering, University of Auckland, Auckland 1023, New Zealand; \\ r.flay@auckland.ac.nz \\ * Correspondence: amir.pirooz@niwa.co.nz
}

check for updates

Citation: Safaei Pirooz, A.A.; Moore, S.; Turner, R.; Flay, R.G.J. Coupling High-Resolution Numerical Weather Prediction and Computational Fluid Dynamics: Auckland Harbour Case Study. Appl. Sci. 2021, 11, 3982. https://doi.org/10.3390/app11093982

Academic Editor: Philip A. Rubini

Received: 31 March 2021

Accepted: 26 April 2021

Published: 28 April 2021

Publisher's Note: MDPI stays neutra with regard to jurisdictional claims in published maps and institutional affiliations.

Copyright: (c) 2021 by the authors. Licensee MDPI, Basel, Switzerland. This article is an open access article distributed under the terms and conditions of the Creative Commons Attribution (CC BY) license (https:/ / creativecommons.org/licenses/by/ $4.0 /)$.
Featured Application: Coupling of very high-resolution NWP and CFD models, as outlined here, could be applied to the study of bias correction in NWP models, natural hazard studies, risk assessment under different extreme weather conditions, and urban and environmental design studies.

\begin{abstract}
In this study, the resilience of large cities and their built infrastructure in New Zealand to extreme winds, is investigated by coupling the outputs of a very high-resolution, 333-m resolution, numerical weather prediction (NWP) model with computational fluid dynamics (CFD) simulations. Following an extreme wind event on 18 September 2020 in Auckland, in which two trucks travelling over the Auckland Harbour bridge tipped over and damaged the bridge structure, a CFD simulation of airflow over the bridge using the Reynolds-averaged Navier-Stokes (RANS) method and NWP wind speed forecasts as the inlet profile is conducted. The $333 \mathrm{~m}$ NWP forecasts were validated against four nearby observation sites, showing generally high correlations of greater than 0.8 and low mean bias $\left( \pm 3 \mathrm{~m} \mathrm{~s}^{-1}\right)$ and RMSE $\left(<3 \mathrm{~m} \mathrm{~s}^{-1}\right)$ values. The CFD-based estimates of the mean wind speed-up over the bridge showed that the mean wind speed could increase by a factor of 1.15-1.20 in the vicinity of the road where the toppled vehicles were travelling. Additionally, NWP forecasts and CFD estimates of wind gusts at the maximum bridge height, within the area not affected by the bridge structure, agreed well with a value of about $25 \mathrm{~m} \mathrm{~s}^{-1}$. An anemometer mounted at the top of the bridge arch measured a higher gust wind speed of about $35 \mathrm{~m} \mathrm{~s}^{-1}$ that could have been influenced by the gust speed-up resulting from the flow separation from the bridge arch, which is demonstrated in the CFD results. The results demonstrate the importance of understanding localised wind speed-up effects and distinguishing them from the approaching undisturbed airflow.
\end{abstract}

Keywords: numerical weather prediction (NWP); downscaling; computational fluid dynamics (CFD); wind hazards; RANS turbulence models; numerical simulation; atmospheric boundary layer

\section{Introduction}

Rapid increases in urbanisation and population of cities, as well as the design and construction of lighter and larger structures, necessitate a better understanding of the urban microclimate and associated hazards to fulfil a need for wind-resistant infrastructures and safer urban environments. Studies have demonstrated that urban climate and conditions not only affect the airflow, but also have a wide range of impacts on the energy use, health, comfort and safety of people [1-3]. Large-scale meteorological disturbances and small-scale wind fluctuations produced by surface terrain and roughness elements are the two main factors characterising the highly variable atmospheric airflow [4]. Although numerical weather prediction (NWP) models are commonly used to simulate and forecast atmospheric flows, they cannot produce the small-scale fluctuations induced by urban roughness elements and finer scale structures. One approach to simulate the airflow characteristics around structures in urban areas is a computational fluid dynamics (CFD) 
technique. The significant increase in numerical simulation capabilities over the last few decades has made it possible to develop high-resolution sub-km weather models and also integrate fine-scale models with coarser models to have realistic initial and boundary conditions [5]. Thus, coupling NWP and CFD models can provide an opportunity to investigate the strong winds over urban areas utilising real meteorological conditions, such as cyclones, thunderstorms, and fronts, as the initial and boundary conditions of the CFD simulations.

The concept of coupling mesoscale NWP models to a CFD model has been studied previously, e.g., [6-9], to investigate various climate and environment parameters in urban areas, such as wind speed and direction, and temperature. CFD simulations can be used to assess urban microclimate by resolving heat and mass transfer and their interaction with buildings and other urban obstacles. Several wind engineering and environmental studies, including wind hazard assessment $[10,11]$, pollutant dispersion and air quality $[6,12,13]$, pedestrian-level wind speeds [14], and energy demand [3,15], significantly benefit from high-resolution CFD simulations of urban areas. Unlike the mesoscale models, which are not capable of resolving urban heterogeneous structures, CFD microscale models have the advantage of accurately resolving the urban roughness sublayer, in which most human activities are located [9]. Reviews of the coupling approach and CFD analysis of urban microclimate are provided by Kadaverugu et al. [5] and Toparlar et al. [1], respectively. In NWP/CFD coupling approaches, both time-varying and non-time-varying boundary conditions provided by the NWP models could be used as inlet conditions to the CFD model. In the present study, non-time-varying boundary conditions are used.

Nakayama et al. [4] coupled a building resolving large eddy simulation (LES) with NWP models to study strong winds during passage of a major typhoon over the central district of Tokyo. For a mesoscale meteorological simulation, they used the Weather Research and Forecasting (WRF) model in a one-way nested configuration downscaling over four computational domains from $4.5 \mathrm{~km}$ to $60 \mathrm{~m}$ horizontal resolution. The horizontal grid spacing of their CFD simulation was $20 \mathrm{~m}$. The results showed that the variations of gust and mean wind speeds within the urban area were well represented in the LES. Using a similar coupling approach to the WRF model with CFD simulations, Li et al. [16] and Temel et al. [17] simulated the airflow over complex terrain using Reynolds-averaged Navier-Stokes (RANS) turbulence models.

Li et al. [10] reproduced the strong winds associated with Typhoon Nuri on 22 August 2008 using a mesoscale model centred on the Hong Kong International Airport. Then, by coupling the mesoscale model with a CFD simulation, they investigated the effects of local topography, hangers and buildings on the significant change in the wind speed observed between the north and south runways from strong wind shear that caused a significant change in the crosswind. For the mesoscale models, the Global Spectral Model of the Japan Meteorological Agency $(100 \mathrm{~km})$, the Regional Spectral Model $(20 \mathrm{~km})$, and Regional Atmospheric Modelling System $(4 \mathrm{~km}, 1.333 \mathrm{~km}$, and $0.444 \mathrm{~km})$ were nested. The 0.444-km mesoscale outputs were used in a CFD simulation using a RANS approach. The CFD results showed that the buildings were the main contributor to the wind speed change, which agreed with the observational data.

Piroozmand et al. [9] investigated the wind and temperature fields in a dense urban area of Zurich, Switzerland during heatwaves, by coupling a regional atmospheric model, COnsortium for Small-scale Modelling (COSMO) [18], with a microscale CFD model utilising the $k-\varepsilon$ unsteady RANS approach. The validation study against a onepoint measurement (identified as the limitation of the validation study by the authors) demonstrated that their coupling approach successfully estimated the diurnal temperature with small errors, while the errors in the wind speed and direction predictions were higher due to the effect of unsteady buoyant flows induced by hot buildings and water bodies, which were captured by the CFD model and not by COSMO.

Germano et al. [19] studied the changes in wind speed and direction in an urban area located in Pescara, Italy, by coupling mesoscale and microscale models. Mesoscale Model 
Fifth Generation (MM5) [20] was used to develop a one-way nested mesoscale model using five domains with the coarsest and finest horizontal resolutions of $32.4 \mathrm{~km}$ and $0.4 \mathrm{~km}$, respectively. The commercial software STAR-CCM+ [21] with the $k-\varepsilon$ unsteady RANS approach was used for the microscale model to investigate wind pattern in two cases: (1) only the topography of the terrain was used; (2) the buildings were added to the model. The results demonstrated the highly localised effects of buildings on wind patterns in urban areas.

Several researchers, e.g., [6,7,12,22], have investigated the wind field and pollutant dispersion patterns in densely built-up urban areas by coupling NWP and microscale CFD simulations. To study the airflow and pollutant dispersion in Seoul, Korea, Baik et al. [6] set up four one-way nested computational domains using the mesoscale MM5 model with the finest horizontal resolution of $1 \mathrm{~km}$. The 1-km NWP outputs provided time-varying boundary conditions for a CFD simulation with a 9.72-m horizontal grid interval, utilising the RANS $k-\varepsilon$ turbulence model. It was demonstrated that, given the complicated patterns of airflow and pollutant patterns in the presence of urban elements and building clusters, time-varying boundary conditions should be used to better estimate the urban flow and dispersion. Then, an NWP/CFD coupled model can reliably predict these patterns. The limitations, however, of this study were outlined by the authors as not considering the surface temperature in the CFD model and the relatively low resolution of the mesoscale model $(1 \mathrm{~km})$. Tewari et al. [22] demonstrated that using the output of a WRF two-way nested mesoscale model ( $0.5 \mathrm{~km}$ finest resolution) as the initial and boundary conditions of a steady CFD simulation considerably enhanced the CFD predictions of pollutant transport. Similarly, Liu et al. [7] coupled the WRF model (five nested domains with $0.5 \mathrm{~km}$ finest resolution) with an LES CFD code to investigate the airflow and pollutant transport patterns in a dense urban area of Beijing. The results of the Yucong et al. [12] study also demonstrated that the coupled WRF/CFD approach is an essential tool in understanding and predicting urban flow and dispersion patterns.

The NWP/CFD coupling techniques have also been employed in the wind energy field for various applications, such as wind energy estimation $[8,23,24]$ and studies of the effects of strong wind events on wind turbines $[25,26]$.

These works demonstrate that the NWP/CFD coupling approach can be reliable and NWP-driven CFD simulations can add significant value to various engineering and environment airflow studies.

On 18 September 2020, gusts associated with a short-lived (10 min) period of strong westerly winds in Auckland caused two trucks to tip over while heading south on the Auckland Harbour Bridge (yellow arrow in Figure 1). The bridge's super structure was damaged in this incident [27] and this resulted in severe disruption to traffic flows while the bridge was closed for damage assessment and repairs. Following this event, we were motivated to investigate two research questions:

1. How accurately does a very high-resolution (i.e., sub-km) NWP model(s) predict such a short-lasting extreme wind event?

2. What are the effects, i.e., wind speed-ups, of the Auckland Harbour Bridge structure itself on the local airflow and is it feasible to couple detailed CFD models with the Auckland Model to produce bridge-specific gust forecasts?

To address these questions, we use sub-km-resolution NWP forecasts of wind speed as the initial and boundary conditions of a CFD simulation using a RANS approach to investigate the airflow around the Auckland Harbour Bridge and to estimate the highly localised wind speed up effects that may have contributed to the vehicle overturning. In addition, a detailed analysis of the sub-km NWP model against local observations during this event is described. 


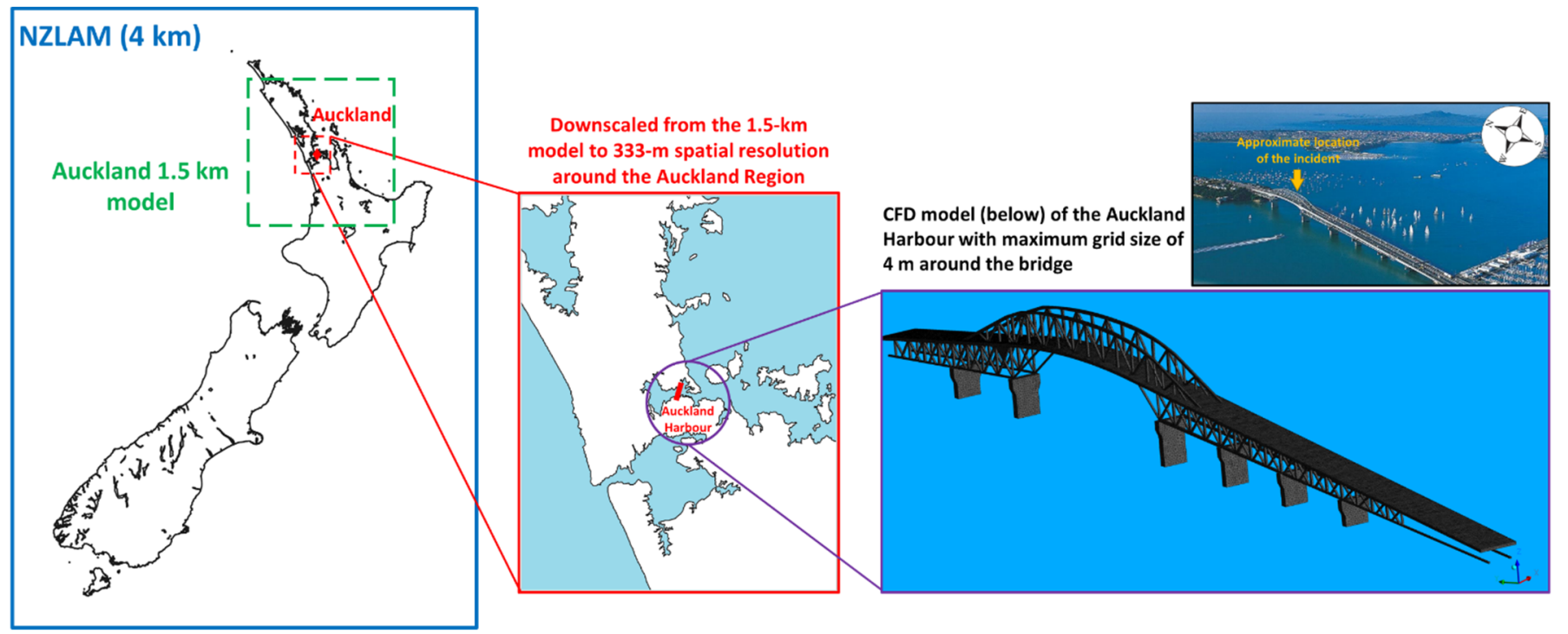

Figure 1. From left to right showing the process of the downscaling the 4-km NZLAM model (full model domain not shown) to 1.5-km (green box) and to the 333-m (red box) around the Auckland region. The outputs of the 333-m model are fed to the CFD simulation with a 4-m grid resolution around the Auckland Harbour Bridge. The yellow arrow shows the approximate location of the truck overturning incident.

The rest of the paper is structured as follows. Section 2 presents a description of the NWP and CFD models and setups, along with the measurement stations used for the validation. The results of the study, including the NWP performance and CFD simulations of the localised winds, are summarised in Section 3. A summary description of how the findings of this study can be used to mitigate wind hazards in urban areas is provided in Section 4. Lastly, conclusions are presented in Section 5.

\section{Methods and Data}

The NWP model used in this study is operated by the National Institute of Water and Atmospheric Research Ltd. NIWA (The National Institute of Water and Atmospheric Research or NIWA), is a Crown Research Institute of New Zealand. Established in 1992, NIWA conducts commercial and non-commercial research across a broad range of disciplines in the environmental sciences. https:/ / www.niwa.co.nz/, accessed on 26 April 2021) and is called the Auckland Model. It is based on the UK Met Office London Model [28] and is a 333-m horizontal resolution convection-permitting configuration of the Unified Model [28,29]. The model set up is $300 \times 300$ horizontal grid-points, centred on the Auckland Harbour Bridge with a terrain-following 140-level vertical coordinate system over the lowest $40 \mathrm{~km}$ of the atmosphere. This increased resolution has shown significant improvements of near surface temperatures [30,31]. The Auckland Model is one-way nested inside NIWA's 4-km resolution NZLAM (New Zealand Limited Area Model), which is data-assimilating and uses the Global Atmosphere 6 science configuration [32] with an intermediate nest at $1.5 \mathrm{~km}$ resolution to ease the transition from $4-\mathrm{km}$ to $333-\mathrm{m}$ resolution. The scientific configuration used is the Regional Atmosphere-Land 2 "Tropical" (RAL2-T) configuration [29]. The Auckland Model is run four times daily out to $36 \mathrm{~h}$ ahead.

Figure 1 shows schematically the process of downscaling the $4 \mathrm{~km}$ NZLAM to the $1.5 \mathrm{~km}$ model and lastly to the 333-m model. It should be noted that the NZLAM4 domain is much larger than just over New Zealand, with its western boundary covering much of eastern Australia and eastern boundary extending past the international dateline. Figure 1 shows only part of NZLAM4 that covers New Zealand. Outputs of the 333-m model were then used to setup the inlet profiles of the CFD model. As can be seen in Figure 1, the CFD domain includes only the isolated bridge model that has most of the main structures of the bridge with the very small details removed. The computational domain extends $3 \mathrm{~km}$ 
horizontally from the centre of the bridge and $1.5 \mathrm{~km}$ vertically to the top of the domain. Relatively fine mesh cells were generated around the bridge with a resolution of $4 \mathrm{~m}$, and even finer down to $0.02 \mathrm{~m}$ around the smaller details of the bridge (see Appendix A, Figure A1). The size of the cells gradually increases far from the bridge (see Appendix A, Figure A2). Tetrahedral cells are used to ensure the complex geometry of the bridge is resolved. The total number of cells is about 32.7 million.

In order to validate the forecasts of the 333-m NWP model, observation data from four stations across the Auckland region were used. Figure 2 shows the locations of the stations (yellow pins) as well as the Auckland Harbour location (red pin). Table 1 summarises the name of the stations used along with their coordinates and wind speed measurement heights above the ground. In the case of the Sky Tower station, there are two anemometers mounted close to the top of the tower at a height of $318 \mathrm{~m}$, with one facing northwest (NW) and the other southeast (SE). Data from both the anemometers are compared with the NWP model at the location of the Sky Tower.

For the event on 18 September 2020, mean and gust wind speed time series (Figure 3) were extracted from the relevant forecast cycle of the 333-m NWP model. Figure 3a shows the model forecasts of the mean wind speeds at different vertical levels upstream of the Auckland Harbour (red pin in Figure 2). Since the RANS approach is used in this study, which only provides time-averaged flow properties, the mean wind speed outputs of the 333-m model were used to define the inlet profiles for the CFD simulation, as shown in Figure 4 . In addition, Figure $3 \mathrm{~b}$ shows the instantaneous and maximum gust wind speeds over a 10-min period at the location of the Auckland Harbour Bridge during the event.

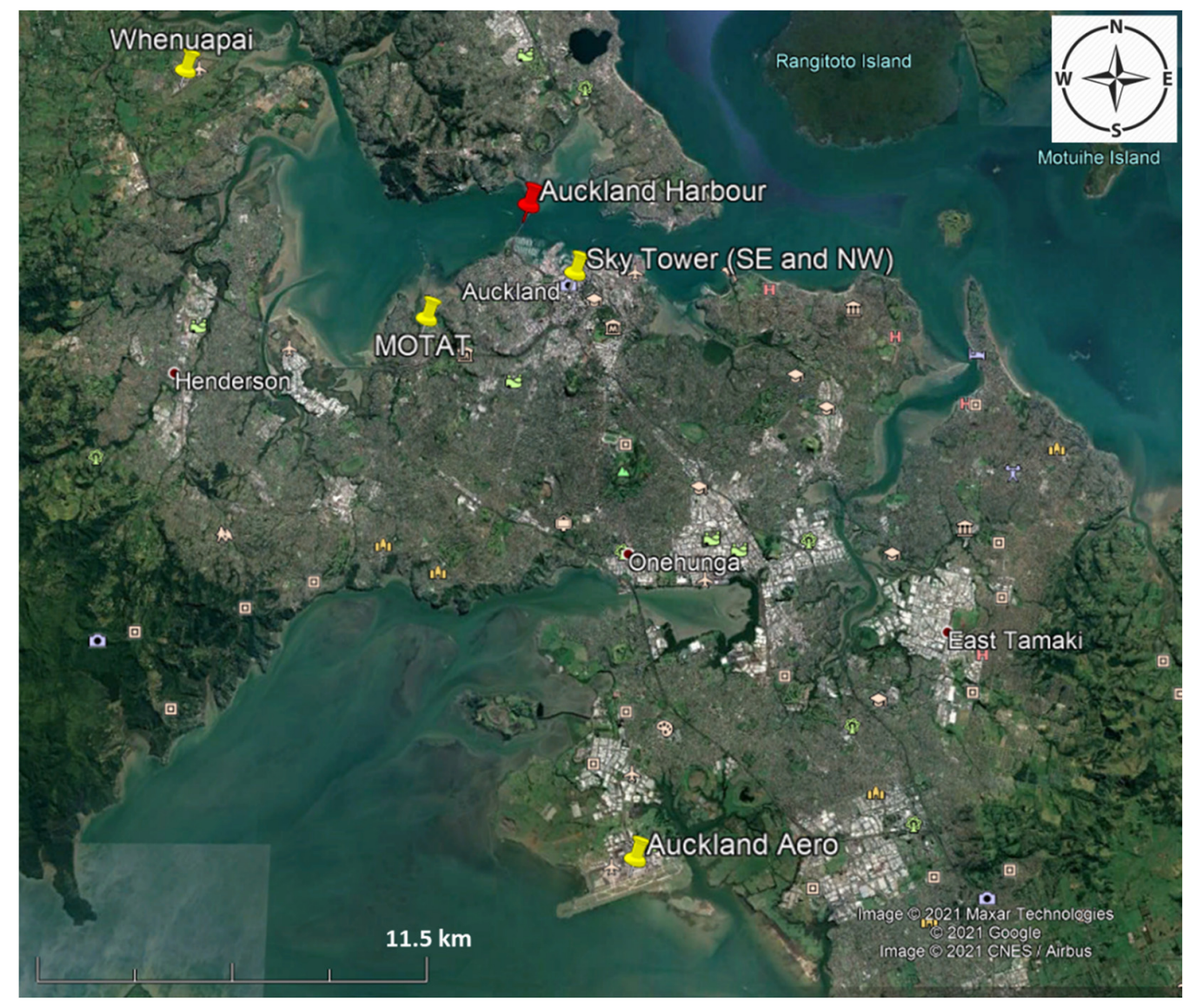

Figure 2. Locations of the measurement sites (yellow pins) used for the validation of the NWP outputs. The red pin shows the location of the Auckland Harbour Bridge. The aerial image is from Google Earth. 
Table 1. List of the measurement stations used for validation along with their coordinates and heights above the ground surface.

\begin{tabular}{cccc}
\hline Station Name & Latitude & Longitude & $\begin{array}{c}\text { Height above the } \\
\text { Ground }\end{array}$ \\
\hline Auckland Aero & -37.00813 & 174.78873 & $10 \mathrm{~m}$ \\
MOTAT EWS & -36.86297 & 174.71185 & $10 \mathrm{~m}$ \\
Whenuapai & -36.79300 & 174.62400 & $10 \mathrm{~m}$ \\
Sky Tower (SE anemometer) & -36.85004 & 174.76242 & $318 \mathrm{~m}$ \\
Sky Tower (NW anemometer) & -36.85004 & 174.76242 & $318 \mathrm{~m}$ \\
\hline
\end{tabular}
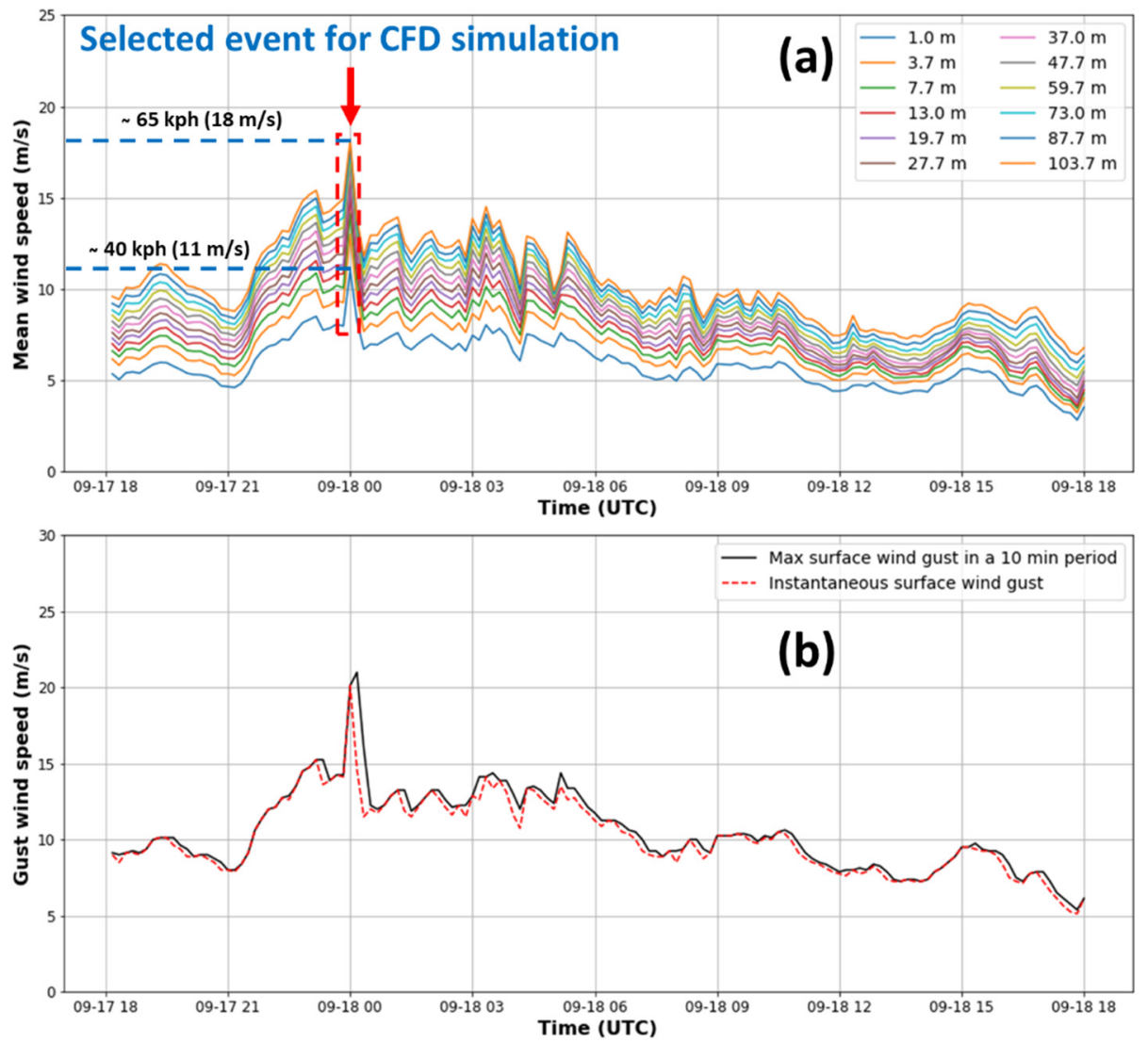

Figure 3. Mean (a) and gust (b) wind speed time series outputs of the $333 \mathrm{~m}$ model upstream of the Auckland Harbour Bridge, during the extreme westerly event on 18 September 2020.

For the CFD simulation, a pressure-driven approach [33] was used to simulate the atmospheric boundary layer (ABL), utilising a three-dimensional, steady RANS simulation using the $k-\omega$ Shear Stress Transport (SST) [34] turbulence model. The mean wind speed forecasts of the event shown in Figure 3a were used to fit the velocity profile (Equation (1), Figure $4 \mathrm{a}$ ) and calculate the friction velocity $\left(u_{*}\right)$. It is shown in Figure $3 \mathrm{a}$ that the forecast mean speeds, and the fitted profile (Figure $4 \mathrm{a}$ ), range from $11 \mathrm{~m} \mathrm{~s}^{-1}$ to $18 \mathrm{~m} \mathrm{~s}^{-1}$ at heights of $1 \mathrm{~m}$ and $103.7 \mathrm{~m}$ above the ground, respectively. Then, the corresponding profiles of the turbulent kinetic energy $(k)$ and turbulent eddy frequency $(\omega)$ (Equations (2) and (3) and Figure $4 \mathrm{~b}, \mathrm{c}$, respectively) were calculated. $U, k$, and $\omega$ profiles were set as the inlet boundary conditions for the computational domain. The symmetry boundary condition is used at the top boundary, the pressure-outlet boundary condition with zerogauge pressure applied at the outlet of the domain, and for the ground, the automatic near-wall treatment [34-36] was applied, replicating the sea surface roughness $\left(z_{0}\right)$ with a roughness length of $0.002 \mathrm{~m}$ [37]. The blending function employed in the SST model allows the use of the attractive near-wall performance [35] of the $k-\omega$ model [38] in the near-wall 
region, and for the rest of the flow, the $k-\varepsilon$ model [39] is utilised. The automatic near-wall treatment switches automatically between wall functions and a low-Reynolds number formulation based on the grid spacing $[35,40]$. A detailed description and formulation of SST and the automatic near-wall treatment can be found in $[35,40]$.
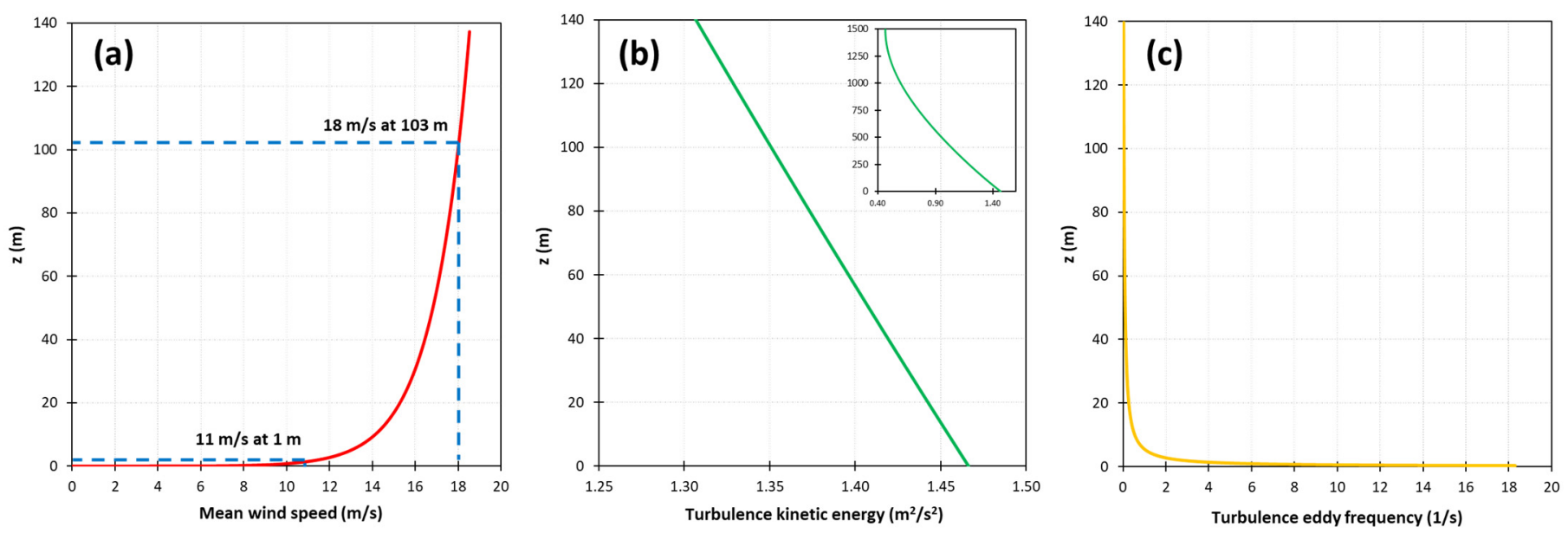

Figure 4. Inlet profiles for the CFD simulation: (a) mean speed; (b) turbulent kinetic energy; (c) turbulent eddy frequency. The smaller graph in the top right of $(\mathbf{b})$ shows the $k$ profile extending to the top of the domain.

The Auckland Harbour Bridge runs effectively south-north and the wind was westerly for the event on 18 September 2020, meaning that the approaching airflow to the bridge is only over water and not over land. Therefore, the isolated bridge setup for the CFD simulation and the sea surface roughness assumption are sensible.

$$
\begin{array}{r}
U(z)=\frac{u_{*}}{\kappa}\left(\ln \left(\frac{z}{z_{0}}\right)+C_{U 1}\left(\frac{z}{H}\right)+C_{U 2}\left(\frac{z}{H}\right)^{2}+C_{U 3}\left(\frac{z}{H}\right)^{3}+C_{U 4}\left(\frac{z}{H}\right)^{4}\right) \\
k(z)=u_{*}^{2}\left(C_{k 1}+C_{k 2}\left(1-\frac{z}{H}\right)^{2}+C_{k 3}\left(1-\frac{z}{H}\right)^{4}+C_{k 4}\left(1-\frac{z}{H}\right)^{6}\right) \\
\omega(z)=\frac{k(z)}{\kappa u_{*} z}\left(1+\left(1+C_{U 1}\right)\left(\frac{z}{H}\right)+\left(1+C_{U 1}+2 C_{U 2}\right)\left(\frac{z}{H}\right)^{2}+\left(1+C_{U 1}+2 C_{U 2}+3 C_{U 3}\right)\left(\frac{z}{H}\right)^{3}\right)
\end{array}
$$

where $z, H$, and $\kappa$ are height above the ground, total domain height, and the von Karman constant $(=0.4)$, respectively. The coefficients $\left(C_{U}\right.$ and $\left.C_{k}\right)$ used in Equations (1)-(3) are calculated by semi-analytical and CFD methods [33]. For more details about the pressure-driven ABL, setting up the boundary conditions and the resulting horizontally homogenous computational domain, see $[33,41]$. The steady RANS equations are solved with the CFD code ANSYS CFX 18.2 [42] using a finite volume method. Both the advection and turbulence terms of the governing equations are discretised using a high-resolution discretisation scheme.

It should be noted that the profiles in Figure 4 are only shown up to $140 \mathrm{~m}$ above the ground for a better visualisation of variables close to the ground. An example of the full $k$ profile extending to the top of the computational domain is shown in Figure $4 \mathrm{~b}$.

The CFD results obtained by solving the RANS equations present the mean flow variables. However, knowing the values of gust wind speeds is of particular importance when studying wind hazards. Thus, to obtain the gust wind speeds $\left(U_{g u s t}\right.$, Equation (6)), the standard deviation ( $\sigma_{u}$, Equation (5)) needs to be approximated using the mean wind speed and turbulent kinetic energy. Popiolek [43] demonstrates that the mean velocity and 
the turbulent kinetic energy obtained from the RANS equations can be utilised to estimate a modified mean wind speed $\left(\overline{W_{e}}\right.$, Equation $\left.(4)\right)$ and $\sigma_{u}$.

$$
\overline{W_{e}}=\left\{\begin{array}{cc}
\bar{U}-0.036 k^{0.5}+0.797 \frac{k}{\bar{U}}-0.179 \frac{k^{1.5}}{\bar{U}^{2}} & \text { if } \frac{k^{0.5}}{\bar{U}}<1.592 \\
0.287 \bar{U}+1.226 k^{0.5} & \text { if } \frac{k^{0.5}}{\bar{U}} \geq 1.592 \\
\sigma_{u}=\bar{U}^{2}-{\overline{W_{e}}}^{2}+2 k .
\end{array}\right.
$$

Using the standard deviation and mean speed values, and assuming that the wind velocity has a Gaussian probability distribution, the gust wind speed can be approximated by Equation (6) [44],

$$
U_{g u s t}=\overline{W_{e}}+\mathrm{g} \sigma_{u}
$$

where $g$ is a peak factor, whose value depends on the effective gust duration and often ranges from 3 (high gust duration, e.g., 3 s) to 3.4 (low gust duration, e.g., $0.2 \mathrm{~s}$ ) [45].

For the validation of NWP estimates of mean and gust wind speeds against observation data, three statistical scores, namely Pearson's correlation, mean bias, and root mean square error (RMSE), are calculated. These are defined as,

$$
\begin{gathered}
\text { Correlation }=\frac{\operatorname{cov}(X, Y)}{\sqrt{\operatorname{var}(X) \cdot \operatorname{var}(Y)}}, \\
\text { Mean Bias }=\frac{\sum_{t=1}^{T}\left(\hat{w}_{t}-w_{t}\right)}{T}, \\
\text { RMSE }=\sqrt{\frac{\sum_{t=1}^{T}\left(\hat{w}_{t}-w_{t}\right)^{2}}{T}},
\end{gathered}
$$

respectively, where $\hat{w}_{t}, w_{t}$ and $T$ are the estimated wind, observed wind, and number of data points, respectively.

\section{Results}

Initially, the performance of the 333-m NWP forecasts during the extreme wind event on 18 September 2020 was validated against observation data from the four nearby stations (Table 1). Then, CFD results are presented to investigate the localised wind speed-ups caused by the structure of the bridge.

\subsection{3-m NWP Model Validation}

The 333-m NWP model provides zonal $(\mathrm{u})$ and meridional $(\mathrm{v})$ components of the mean wind speed at $10 \mathrm{~m}$ (as a diagnosed quantity) above the ground (taken as the model's surface) as well as at up to 140 vertical levels above model surface (as model prognostic quantities), separately. The gust wind speed is only estimated at $10 \mathrm{~m}$ above the ground. The mean and gust wind speed outputs of the NWP are compared with the station observations for the period 17 September 2020 18:00 UTC to 18 September 2020 18:00 UTC in Figures 5 and 6. NWP mean wind speeds at three vertical levels, namely $7.7 \mathrm{~m}, 10 \mathrm{~m}$ and $13.7 \mathrm{~m}$ above the surface, are compared with the $10-\mathrm{m}$ anemometer measurements at each station location.

At the Auckland Aero location (Figure 5a), the forecast gust wind speed values and the time of occurrence of the maximum gust speed (18 September 00:00 UTC) agrees well with those of the observation. However, the NWP model slightly underestimates the mean wind speeds. In addition, there is a difference of up to $5 \mathrm{~m} \mathrm{~s}^{-1}$ between the forecast and station gust wind speed at Auckland between 18 September 6:00 UTC and 9:00 UTC. It is noteworthy that the mean speed values at $10-\mathrm{m}$ and $7.7-\mathrm{m}$ heights provided by the NWP model are very similar at all station locations. The strong gust wind speed on 18 September at 00:00 UTC is also accurately forecast at the Whenuapai location, while later in the day (9:00 UTC to 12:00 UTC), the model underestimates the gust values. 

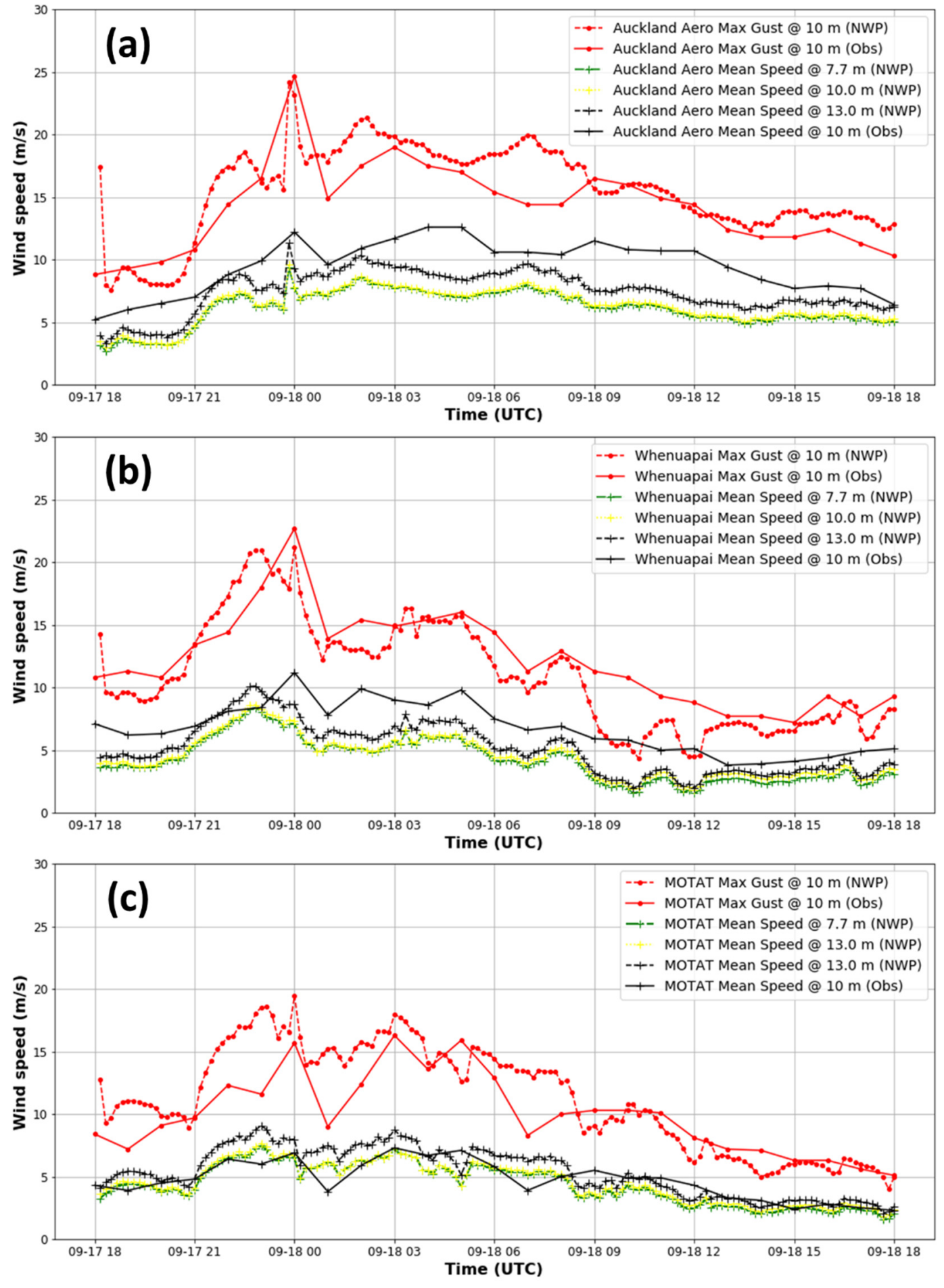

Figure 5. Comparison of gust and mean wind speeds during 17 September 2020 18:00 UTC to 18 September 2020 18:00 UTC from the 333-m NWP model and observations, at: (a) Auckland Aero; (b) Whenuapai; (c) MOTAT. 

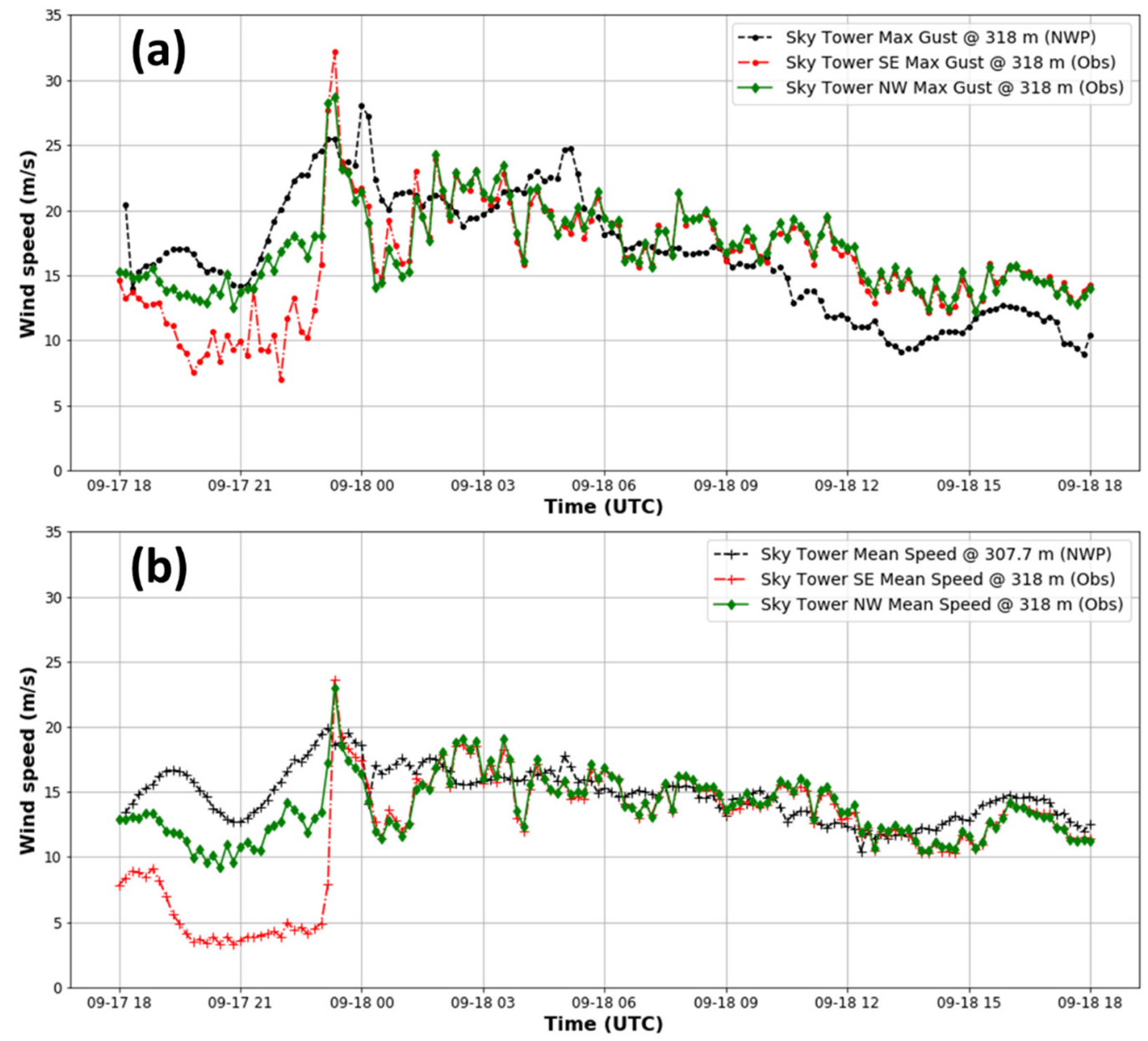

Figure 6. Comparison of (a) gust and (b) mean wind speeds during 17 September 2020 18:00 UTC to 18 September 2020 18:00 UTC from the 333-m NWP model and the two anemometers mounted on the Sky Tower.

Regarding the mean wind speed at Whenuapai (Figure 5b), the NWP model underestimates the values after 00:00 UTC on 18 September by about $2 \mathrm{~m} \mathrm{~s}^{-1}$ on average. In addition, the maximum mean wind speed was predicted at 22:30 UTC as opposed to 00:00 UTC (observation). At MOTAT (Figure 5c), the forecast mean and gust wind speeds generally agree well with the observations, the model occasionally forecasting higher gust wind speeds compared with observations.

The maximum gust wind speed measured and forecast on 18 September at 00:00 UTC is the highest at the Auckland Aero station with a value close to $25 \mathrm{~m} \mathrm{~s}^{-1}$, which drops to $22.5 \mathrm{~m} \mathrm{~s}^{-1}$ at Whenuapai. Wind speeds at MOTAT are smaller compared with the other stations, which could be explained by the surrounding suburban terrain of MOTAT. In addition, at Auckland and Whenuapai, the modelled mean wind speed at a 13-m height agreed slightly better with the observation values.

The strong wind event in Auckland on 18 September 2020 was a westerly event. Thus, it is expected that the anemometer facing NW near the top the Sky Tower is more exposed to the approaching wind and is thus able to measure the wind speeds more accurately. For more details about the Sky Tower anemometers and the sheltering effects of the tower, see [46].

Figure 6 compares the measurements of both Sky Tower anemometers with the forecasts of the NWP model. For the mean wind speeds, the NWP outputs at higher levels were used. However, the 10-m gust wind speed at the location of the Sky Tower was extrapolated to a height of $318 \mathrm{~m}$ using the terrain/height multipliers provided in [37]. It is evident that the NW anemometer measurements agree considerably better with the model 
data, particularly for the hours before the maximum event, i.e., 18 September at 23:00 UTC. It should be noted that the maximum wind speed at Sky Tower is recorded at 23:00, as opposed to 00:00.

Statistical metrics were computed for both the gust and mean wind speeds between the forecast and observed data and the results summarised in Table 2. All the stations, except for the Sky Tower, showed high Pearson's correlations, generally higher than 0.80 . Whenuapai had the highest correlations.

Table 2. Summary statistics for comparison between the observed and Auckland Model forecast gust and mean wind speeds at the location of the four stations.

\begin{tabular}{ccccccc}
\hline & \multicolumn{3}{c}{ Max Gust Wind Speed } & \multicolumn{3}{c}{ Mean Wind Speed } \\
\hline Station Name & Correlation & Mean Bias & RMSE & Correlation & Mean Bias & RMSE \\
\hline Auckland Aero & 0.87 & 1.32 & 2.22 & 0.80 & -2.08 & 2.39 \\
Whenuapai & 0.93 & -1.14 & 2.15 & 0.85 & -1.60 & 1.97 \\
MOTAT & 0.81 & 1.24 & 2.91 & 0.76 & 0.62 & 1.45 \\
Sky Tower (SE anemometer) & 0.47 & -3.73 & 5.44 & 0.15 & 2.57 & 5.14 \\
Sky Tower (NW anemometer) & 0.65 & -4.67 & 5.42 & 0.49 & 1.03 & 2.44 \\
\hline
\end{tabular}

The NW anemometer on the Sky Tower agreed better with the forecasts of the NWP model with a correlation of 0.65 and 0.49 for gust and mean wind speeds, respectively. The mean bias and RMSE values at Auckland Aero, Whenuapai and MOTAT range from -2 to 1.3 and 1.45 to 2.91, respectively. Both RMSE and bias values at the Sky Tower are higher than those of the other stations.

\subsection{CFD Results}

Velocity streamlines for the westerly wind on 18 September 2020 passing through the Auckland Harbour Bridge are shown in Figure 7a, depicting wind speed-ups on the edge of the road as well as between the struts of the bridge. Figure $7 \mathrm{~b}$ depicts the mean speed on a plane at the centre of the bridge along the road. The locations of high (red) and low (blue) wind speeds can be seen. The sheltering effects of the bridge components result in lower wind speeds.
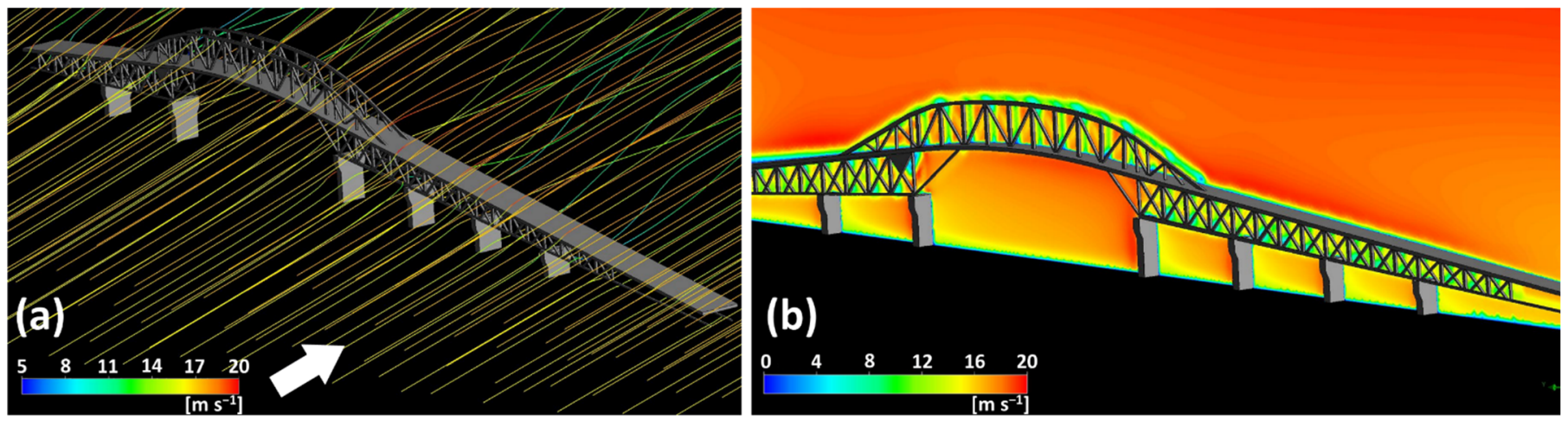

Figure 7. Overall airflow behaviour around the harbour for the westerly wind: (a) velocity streamlines; (b) contour of mean speed at the centre of the harbour.

To better realise the flow pattern across the width of the bridge, the results are presented on two cross-sectional planes (Figure 8). Figure 9a,c and Figure $9 \mathrm{~b}, \mathrm{~d}$ show the mean wind speed and wind speed-ups on these planes, respectively. The wind speed-up is defined as the wind speed at a specific location and elevation divided by the undisturbed upstream wind speed at the same elevation. The location of Plane 1 is chosen such that it goes in-between the side struts of the bridge, while Plane 2 goes through a vertical beam. The planes are selected to illustrate how the area reduction due to the presence of the 
bridge structure (Plane 1) results in wind speed-up (Figure 9a). On the other hand, wind speeds on Plane 2 depict the sheltering effect behind the vertical beam (Figure $9 b$ ).

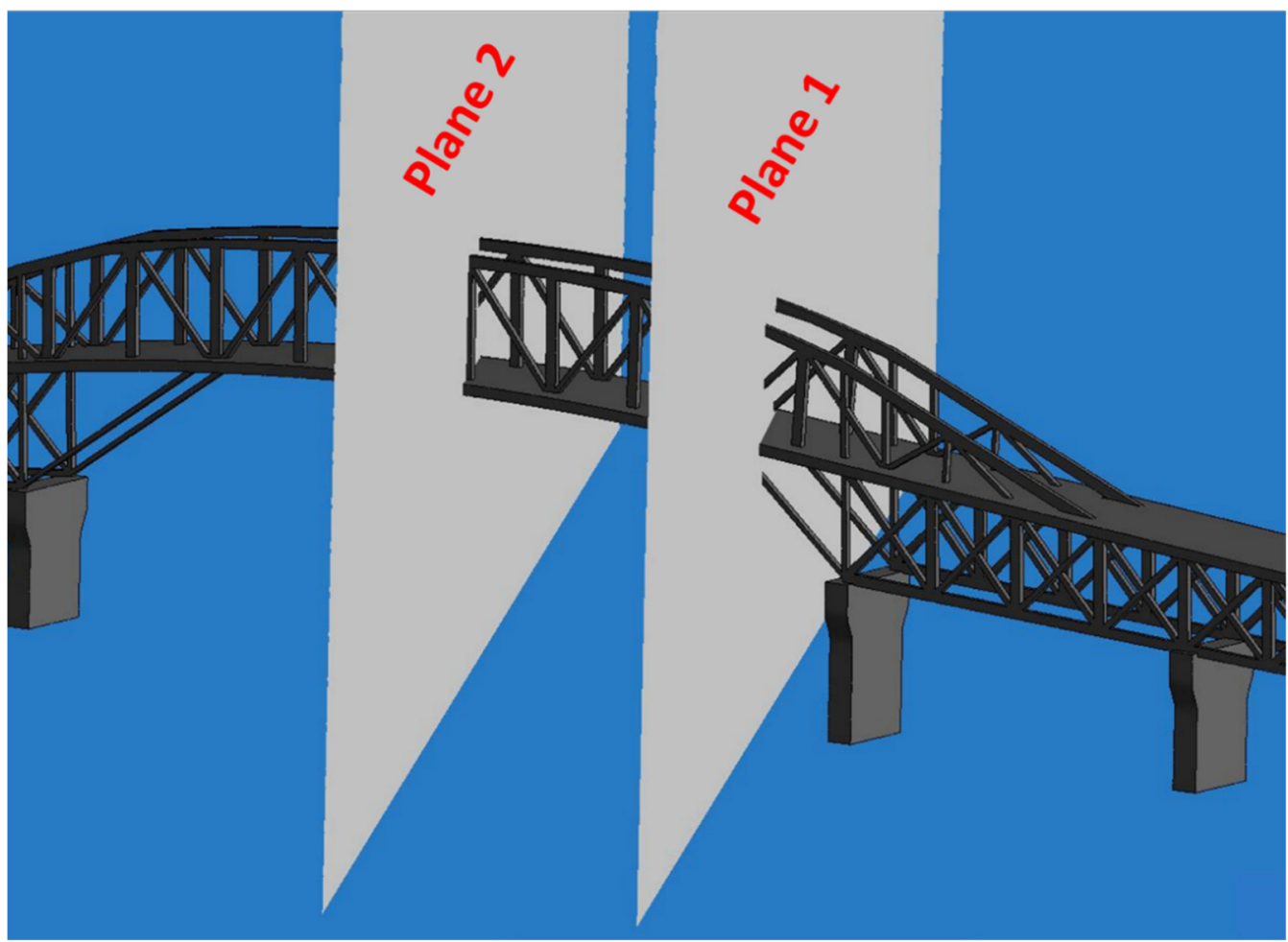

Figure 8. Two cross-sectional planes selected to present the wind speed results.

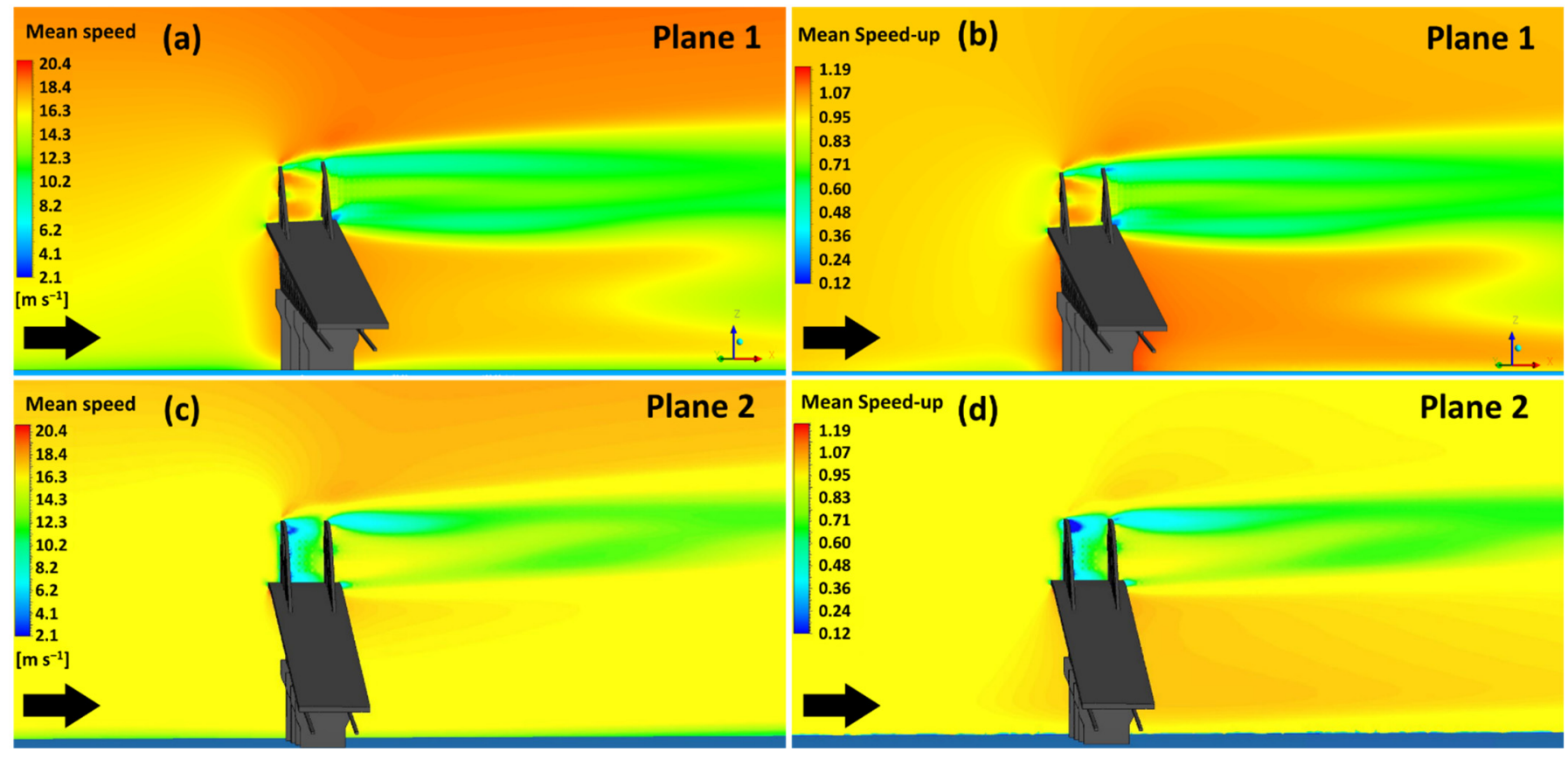

Figure 9. Wind speed results on two cross-sectional planes along the width of the bridge: (a) mean speed on Plane 1; (b) mean speed-up on Plane 1; (c) mean speed on Plane 2; (d) mean speed-up on Plane 2.

It can be seen in Figure $9 \mathrm{~b}$ that the mean speed on Plane 1 can be increased by up to 1.15-1.20 in the middle of the bridge where vehicles travel. This speed-up is due the sudden reduction in the area between the struts. In contrast, on Plane 2 (Figure 9d), the 
wind speed-up is considerably less than 1.0 (blue region in the middle of the bridge), which is because of the sheltering effect of the structure. This illustrates the significant variability of wind speed along the bridge. It is also noteworthy that the wake created by the bridge extends far downstream of the bridge.

The NWP gust wind speed timeseries presented in Figure 3b was gust wind speed at $10 \mathrm{~m}$ above the ground. The maximum height of the Auckland Harbour Bridge is $64 \mathrm{~m}$. Therefore, to estimate the gust wind speed at the top of the bridge, the values in Figure $3 \mathrm{~b}$ are multiplied by a height/terrain factor obtained from Table 4.1 of [37]. The NWP gust speed timeseries at 10-m and 64-m heights are compared in Figure 10. It can be seen that the maximum gust wind speed during this event at $64-\mathrm{m}$ is $25 \mathrm{~m} \mathrm{~s}^{-1}$.

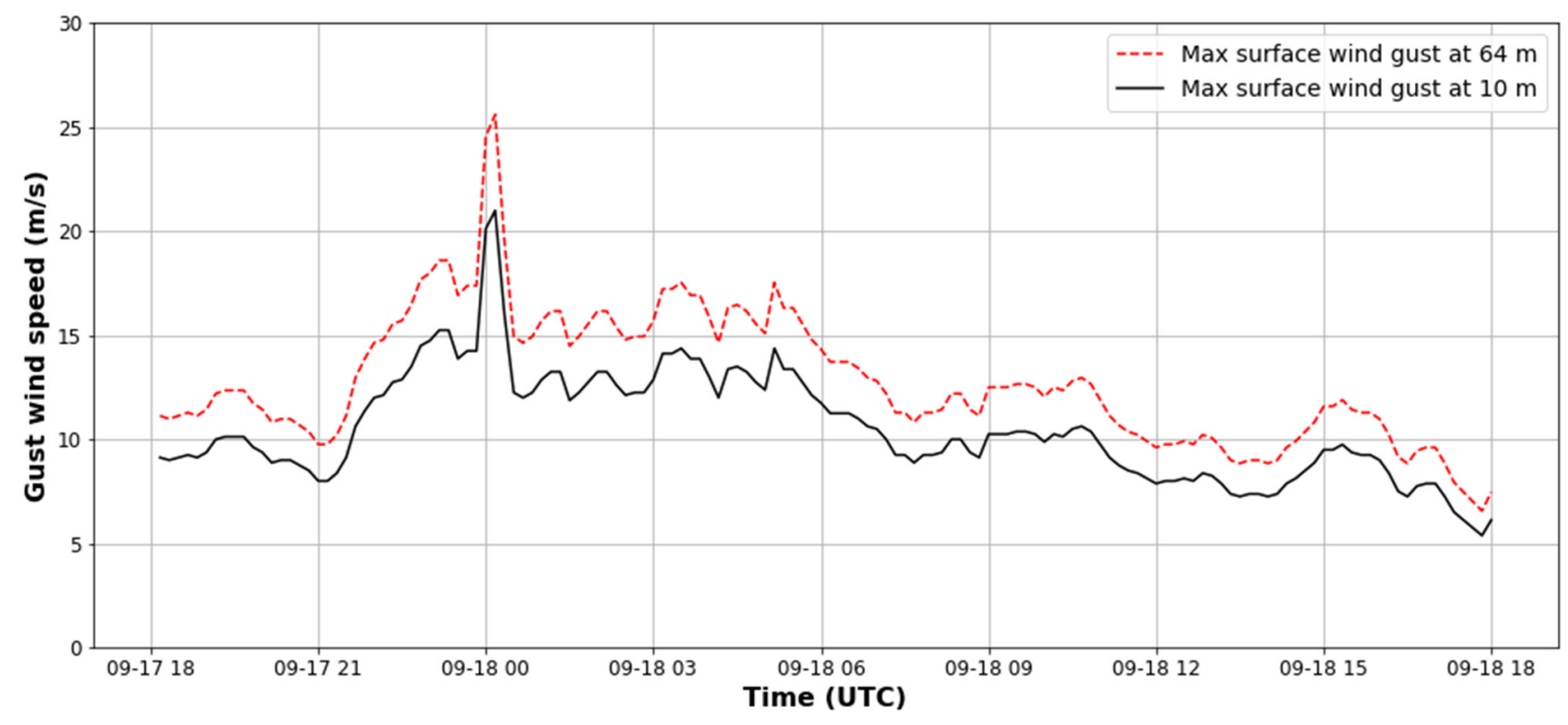

Figure 10. Comparison between NWP gust wind speed timeseries at $10 \mathrm{~m}$ and $64 \mathrm{~m}$ above the ground.

Gust wind speeds across the bridge estimated using mean wind speed and turbulent kinetic energy (Equations (4)-(6)) on both Plane 1 and 2 are shown in Figure 11. On Plane 1 (Figure 11a), the gust wind speeds reach around 22-24 m s${ }^{-1}$ close to the surface of road and flow separation is observed from the top arch of the bridge with high gust wind speeds of about $25-30 \mathrm{~m} \mathrm{~s}^{-1}$. On Plane 2 (Figure 11b), the gust wind speeds close to the surface are smaller, due to the sheltering, and range from $12 \mathrm{~m} \mathrm{~s}^{-1}$ to $14 \mathrm{~m} \mathrm{~s}^{-1}$. In addition, the flow separation from the bridge arch is smaller with values slightly less than those on Plane 1. The gust wind speeds obtained from the CFD above the top of the bridge (not in the separation zone), ranging $24-25 \mathrm{~m} \mathrm{~s}^{-1}$, are close to the NWP gust wind speeds extrapolated to a $64-\mathrm{m}$ height (Figure 10).

Via personal communication with "Total Bridge Services", who manage the Auckland Harbour Bridge operations, it was confirmed that there is an anemometer at the top of the arch that recorded a maximum gust of $127 \mathrm{~km} \mathrm{~h}^{-1}=35.3 \mathrm{~m} \mathrm{~s}^{-1}$ during the event on 18 September 2020. It is clear from Figure 11 that the region above the top arch is affected by flow separation and has higher gust wind speeds, which may not reflect the real upstream wind speed, nor be captured accurately by the 333-m NWP model (Figure 3b). Given the accuracy of the NWP model in predicting the value of the strong winds compared with observations, as shown in Figures 5 and 6, it can be said that the $35 \mathrm{~m} \mathrm{~s}^{-1}$ measurements by the anemometer mounted above the bridge arch were affected by the speed-up effect of the structure (Figure 11), and most likely, did not represent the approaching wind speed. 

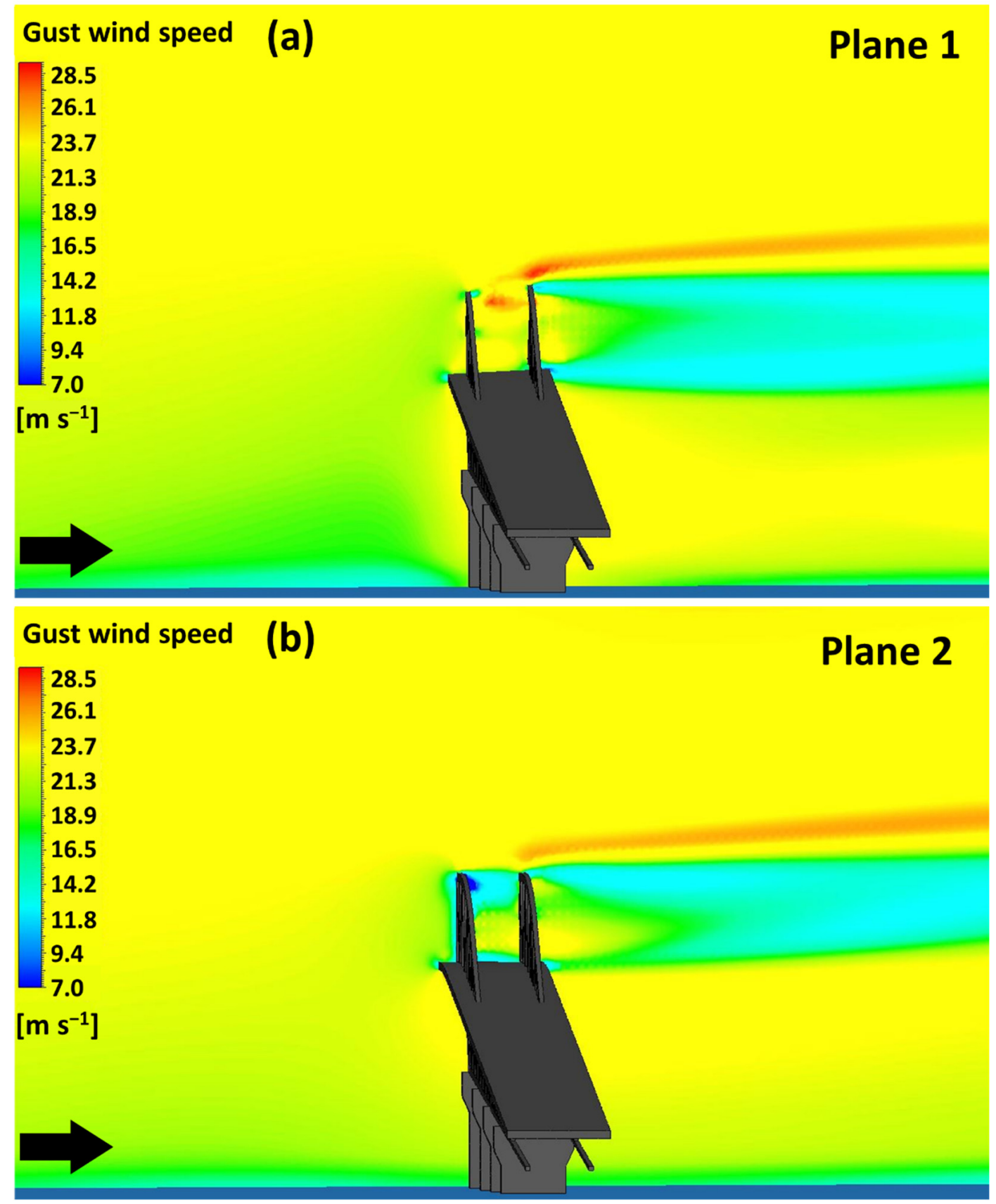

Figure 11. Estimated gust wind speed (Equations (4)-(6)) on the two cross-sectional planes (see Figure 8) of the Auckland Harbour Bridge: (a) Plane 1; (b) Plane 2.

In Figure 3a, it was shown that at a height of $103.7 \mathrm{~m}$, the mean forecast speed was $18 \mathrm{~m} \mathrm{~s}^{-1}$. The bridge has a clearance height of about $43 \mathrm{~m}$ (water to roadway). Figure 12 illustrates velocity iso-surfaces, showing locations where the wind speed is $18 \mathrm{~m} \mathrm{~s}^{-1}$. It is evident that the structure of the bridge affects the upstream airflow such that a mean wind speed of $18 \mathrm{~m} \mathrm{~s}^{-1}$ is predicted on the roadway of the bridge. 


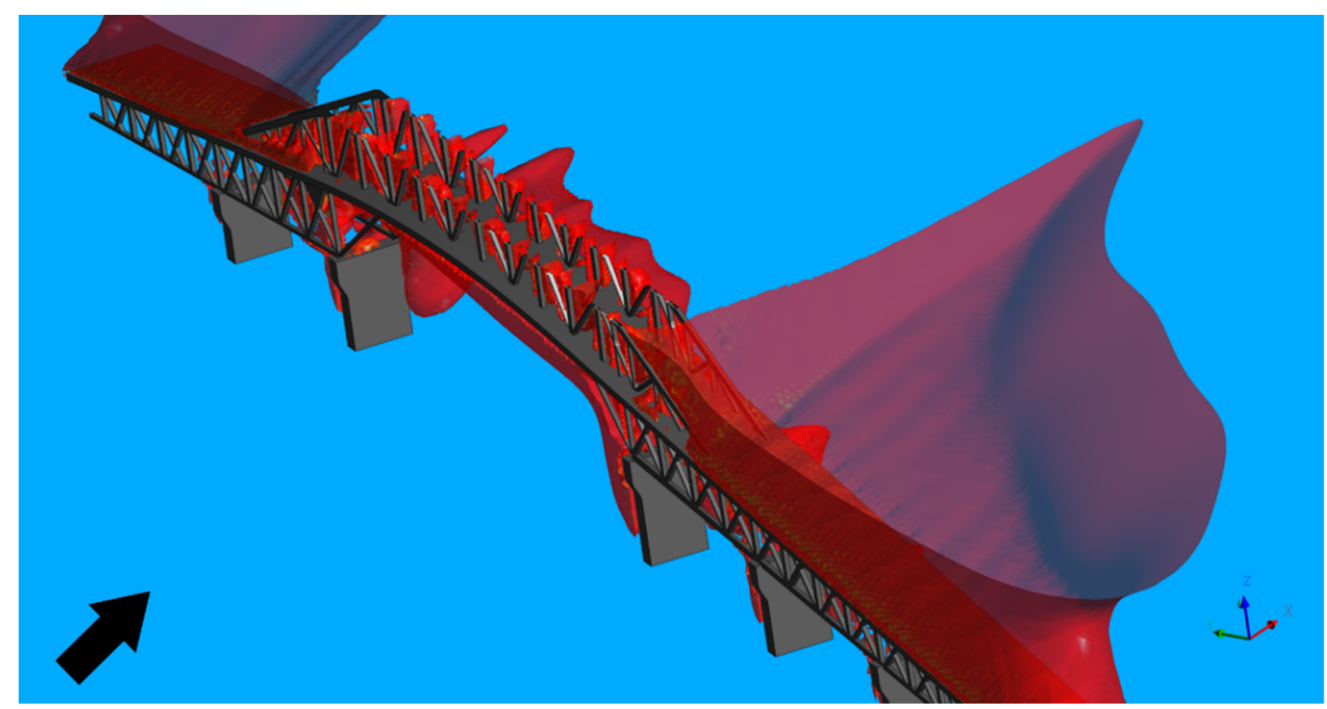

Figure 12. Velocity iso-surface showing the locations where the velocity is $18 \mathrm{~m} \mathrm{~s}^{-1}$. The top arch is removed from the visualisation to show the iso-surface on the road more clearly.

\section{Discussion}

The validation of the performance of very high-spatial resolution (333-m), state-of-theart NWP model against four observation data in the region demonstrated that the model accurately predicted the strong westerly wind on 18 September 2020 in Auckland. Both gust and mean wind speed forecasts showed high statistical scores against observations. Accurate predictions of the value and time of the extreme wind event by the NWP model show a great potential in mitigating wind hazards in urban areas by developing risk forecast models and warning systems.

The coupling of the NWP model with CFD simulations demonstrated that wind speeds can vary significantly in a small spatial scale due to the localised effects of structures, which are not captured by NWP models. It was shown that the bridge structure can either shelter the incoming airflow or increase the mean wind speed by up to $20 \%$ at the middle of the bridge where vehicles travel. In addition, the CFD results simulated the flow separation from the top of the bridge arch, where an anemometer is mounted.

Several studies have investigated the cross-wind speed required to tip over vehicles with different sizes, e.g., [47-49]. Knowing these criteria along with the wind speed-ups and variations along the bridge could be used to develop a forecast model for the bridge, similar to the Vehicle OverTurning (VOT) Model proposed by [50]. The forecast model will be beneficial to operational meteorologists when issuing weather warnings. The model will be able to identify the occurrence of high-wind conditions and prevent accidents such as the one that happened on 18 September 2020 in Auckland, New Zealand, and the subsequent costs and disruptions.

The importance of having a warning system becomes more noticeable when we consider the average reoccurrence interval of strong wind events. For instance, for the westerly wind that happened in Auckland, New Zealand, it was reported that at the time that the trucks were tipped over on the bridge, the gust speed was $35 \mathrm{~m} \mathrm{~s}^{-1}$ (neglecting the effect of the flow separation from the bridge arch). It is instructive to use New Zealand's wind loading standard, AS/NZS1170.2:2011 [37] to estimate the return period of such gusts. This analysis can provide useful information on how frequently they might have occurred in the past, and whether or not it was a "freak" gust, as reported in the media.

For wind from the westerly quarter, the upstream fetch is the water of the Waitemata Harbour and is Terrain Category 1. Using Table 4.1 in [37], we can relate this gust speed to a gust speed at a height of $10 \mathrm{~m}$ in Terrain Category 2, which is the reference conditions for the standard. 
The maximum height of the bridge is $64 \mathrm{~m}$. If the anemometer height is taken as $64 \mathrm{~m}$, then according to [37], the terrain/height multiplier is 1.26 and is not particularly sensitive to height. This means that a gust of $35.3 \mathrm{~m} \mathrm{~s}^{-1}$ at the bridge corresponds to a gust of $35.3 / 1.26=28 \mathrm{~m} \mathrm{~s}^{-1}$ at the standard conditions at a height of $10 \mathrm{~m}$ in terrain category 2 .

Referring to the regional wind speed for New Zealand (Table 3.1 in [37]), it is evident that a wind speed of $30 \mathrm{~m} \mathrm{~s}^{-1}$ corresponds to a return period of 1 year, and so interestingly, this means that according to the wind loading standard, the gust that tipped the trucks over in September 2020 can be expected to occur more often than annually. Therefore, perhaps the fact that trucks have not been tipped over more frequently on the bridge is because a high-sided light truck has not been in the high gust speed location at the same time as it has occurred.

The coupling of NWP and CFD performed in this study can be extended to other parts of Auckland, or any other city, to investigate the resilience of infrastructure against strong wind events.

Lastly, although the steady RANS approach used in the present study was able to capture the main features of the airflow around the bridge and the simulated mean wind speeds and estimated gust wind speeds were in good agreement with the observations, unsteady and LES approaches along with time-varying boundary conditions should be used to predict and model transient and short-duration gusts to investigate the potential wind hazards in more detail and with higher accuracy.

\section{Conclusions}

The study investigated the coupling of a very high-resolution NWP model over Auckland, New Zealand, with a grid size of $333 \mathrm{~m}$, to a CFD model. The primary aim was to assess the 333-m model's performance during a high-impact wind event in Auckland on 18 September 2020, and also to carry out a CFD simulation of the airflow around the Auckland Harbour Bridge using a RANS approach. The validation of the NWP forecast data against four stations across the Auckland region showed that the NWP model successfully and accurately predicted the mean and gust wind speeds. The CFD simulations demonstrated that the bridge influences the incoming airflow such that the mean speed on the road can increase by up to 1.2 compared with the undisturbed upstream flow. In addition, while underestimating the observed mean and gust wind speeds at the bridge, coupling the 333-m NWP and CFD models shows promise for better predicting wind speeds around natural and built structures during extreme wind events, since the CFD model can better model the fine-scale effects on local winds that are missing from an NWP model that does not see the finer structures, for various reasons, e.g., computational cost, science design and purpose of the model. It has been demonstrated how small scales of surface roughness and geometrical details (in CFD models) can cause significant variations of local wind conditions (so-called "local-scale forcing effects").

Gaining a better understanding of the detailed airflow patterns over the Auckland Harbour Bridge can aid in developing a warning system to avoid events like the one that happened on 18 September 2020. More work is underway to use large eddy simulation (LES) instead of RANS to study the flow patterns in more detail as well as advancing our capability in coupling NWP outputs to CFD simulations.

Author Contributions: Conceptualisation, A.A.S.P., S.M., R.T. and R.G.J.F.; methodology, A.A.S.P. and S.M.; validation, A.A.S.P. and S.M.; formal analysis, A.A.S.P. and S.M.; investigation, A.A.S.P., S.M., R.T. and R.G.J.F.; data curation, S.M. and A.A.S.P.; writing-original draft preparation, A.A.S.P.; writing-review and editing, A.A.S.P., S.M., R.T. and R.G.J.F.; visualization, A.A.S.P. and S.M.; supervision, R.T. and R.G.J.F. All authors have read and agreed to the published version of the manuscript.

Funding: This work was supported in part by the Weather and Wildfire Theme of the Resilience to Nature's challenge funded by New Zealand's Ministry of Business Innovation and employment as well as by NIWA through that Climate and Forecasting program of NIWA's Strategic Science Investment Fund (projects CAFS2101 and CAFS2103). The authors wish to acknowledge the use of New Zealand eScience Infrastructure (NeSI) high performance computing facilities, consulting 
support and/or training services as part of this research. New Zealand's national facilities are provided by NeSI and funded jointly by NeSI's collaborator institutions and through the Ministry of Business, Innovation \& Employment's Research Infrastructure programme (https: / / www.nesi.org.nz, accessed on 26 April 2021). The authors would like to acknowledge Total Bridge Services for the wind data from the anemometer mounted on top of the bridge, and New Zealand MetService for SYNOP and maximum gust records from the Auckland Aero and Whenuapai stations.

Conflicts of Interest: The authors declare no conflict of interest.

\section{Appendix A}

The figures below show the CFD mesh grids on the bridge (Figure A1), around the bridge (Figure A2) and how the grid size gradually increases far from the bridge structure.

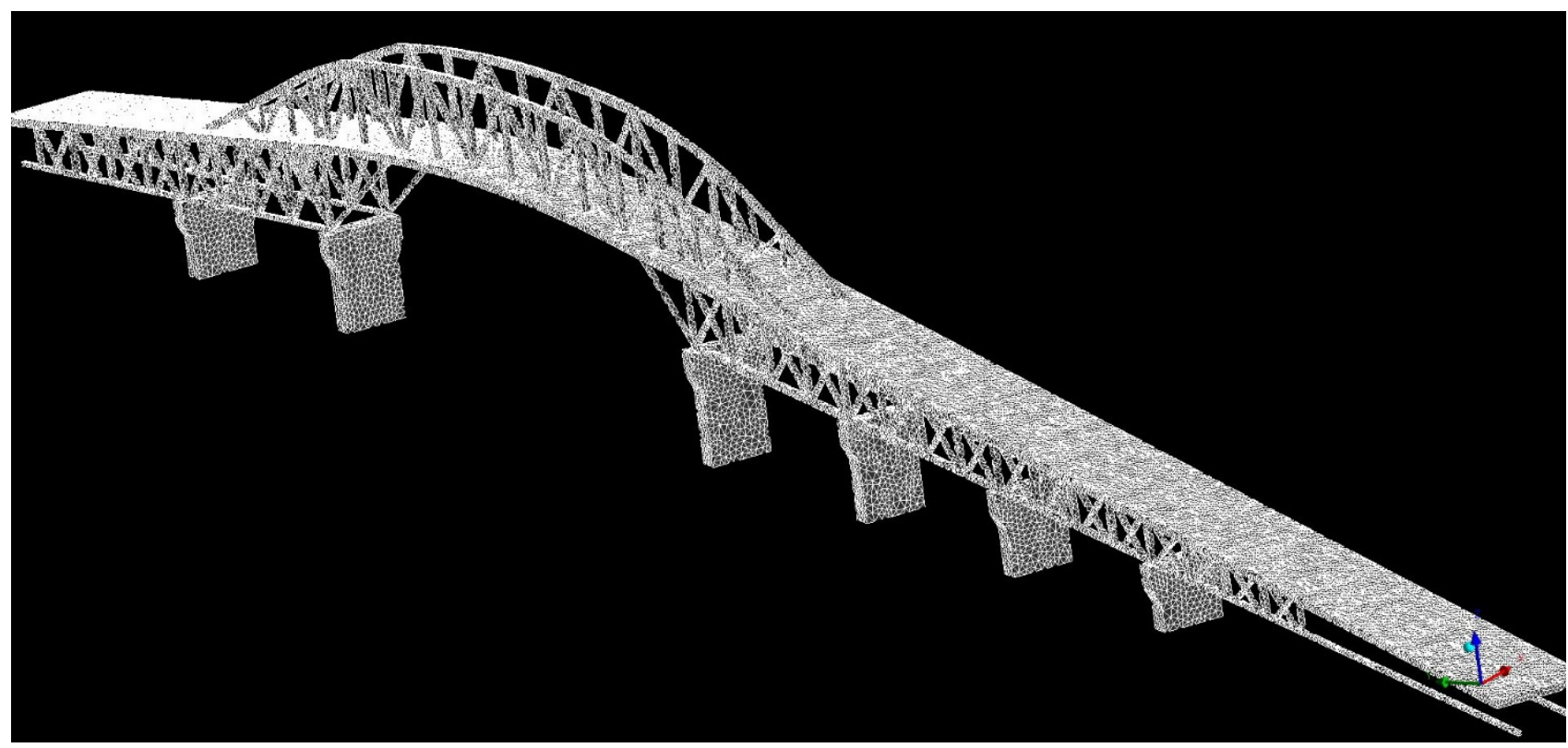

Figure A1. Tetrahedral mesh cells around the bridge with a resolution of $4 \mathrm{~m}$, and even finer down to $0.02 \mathrm{~m}$ around the smaller details of the bridge.

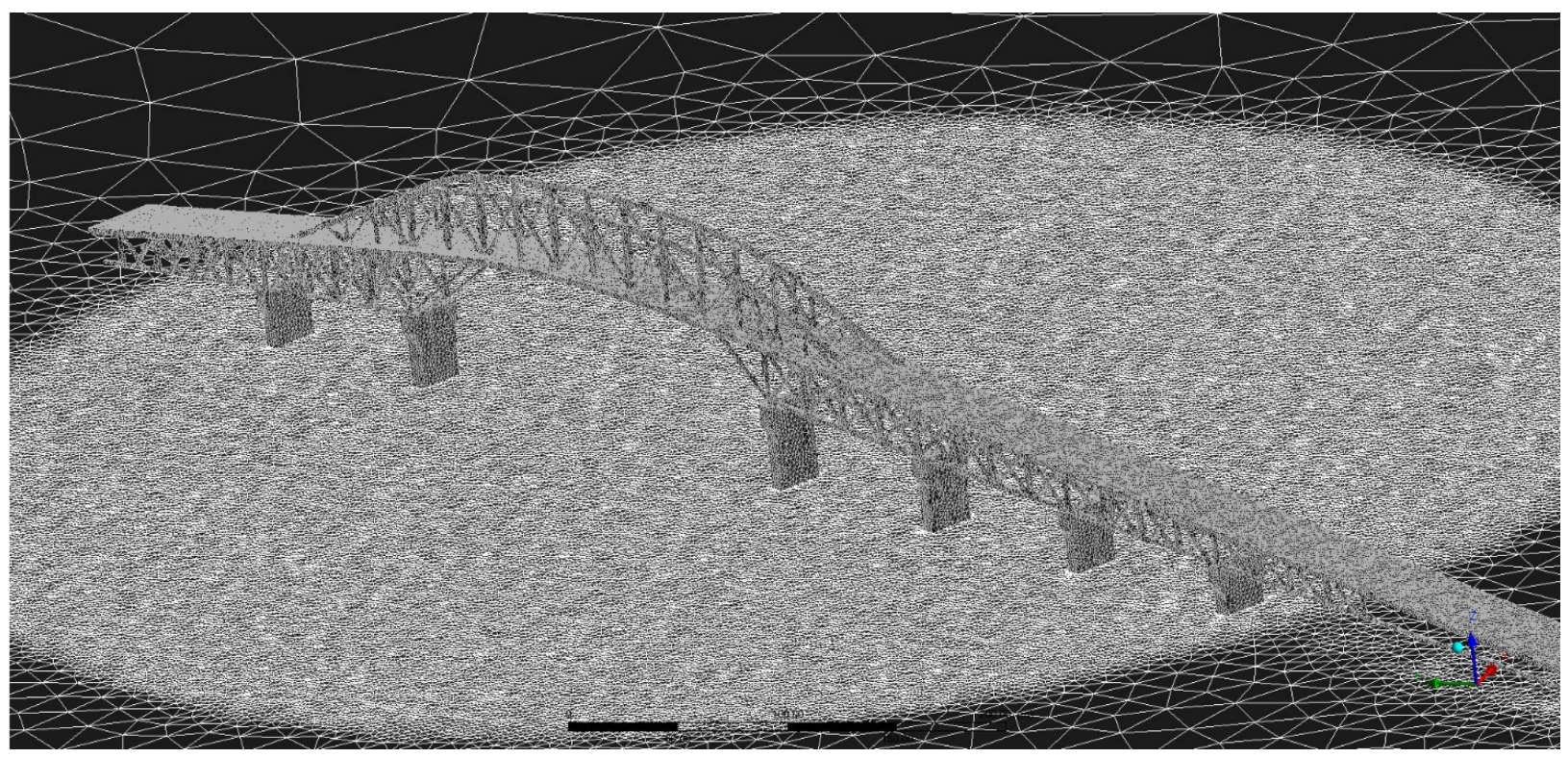

Figure A2. The size of the CFD cells gradually increases far from the bridge. 


\section{References}

1. Toparlar, Y.; Blocken, B.; Maiheu, B.; van Heijst, G.J.F. A review on the CFD analysis of urban microclimate. Renew. Sustain. Energy Rev. 2017, 80, 1613-1640. [CrossRef]

2. Toparlar, Y.; Blocken, B.; Vos, P.; van Heijst, G.J.F.; Janssen, W.D.; van Hooff, T.; Montazeri, H.; Timmermans, H.J.P. CFD simulation and validation of urban microclimate: A case study for Bergpolder Zuid, Rotterdam. Build. Environ. 2015, 83, 79-90. [CrossRef]

3. Moonen, P.; Defraeye, T.; Dorer, V.; Blocken, B.; Carmeliet, J. Urban Physics: Effect of the micro-climate on comfort, health and energy demand. Front. Archit. Res. 2012, 1, 197-228. [CrossRef]

4. Nakayama, H.; Takemi, T.; Haruyasu, N. Coupling of WRF and building-resolving urban CFD models for analysis of strong winds over an urban area. In Proceedings of the 14th Conference on Mesoscale Processes, American Meteorological Society, Los Angeles, CA, USA, 31 July-1 August 2011.

5. Kadaverugu, R.; Sharma, A.; Matli, C.; Biniwale, R. High Resolution Urban Air Quality Modeling by Coupling CFD and Mesoscale Models: A Review. Asia-Pac. J. Atmos. Sci. 2019, 55, 539-556. [CrossRef]

6. Baik, J.-J.; Park, S.-B.; Kim, J.-J. Urban Flow and Dispersion Simulation Using a CFD Model Coupled to a Mesoscale Model. J. Appl. Meteorol. Climatol. 2009, 48, 1667-1681. [CrossRef]

7. Liu, Y.S.; Miao, S.G.; Zhang, C.L.; Cui, G.X.; Zhang, Z.S. Study on micro-atmospheric environment by coupling large eddy simulation with mesoscale model. J. Wind Eng. Ind. Aerodyn. 2012, 107-108, 106-117. [CrossRef]

8. Durán, P.; Meißner, C.; Casso, P. A new meso-microscale coupled modelling framework for wind resource assessment: A validation study. Renew. Energy 2020, 160, 538-554. [CrossRef]

9. Piroozmand, P.; Mussetti, G.; Allegrini, J.; Mohammadi, M.H.; Akrami, E.; Carmeliet, J. Coupled CFD framework with mesoscale urban climate model: Application to microscale urban flows with weak synoptic forcing. J. Wind Eng. Ind. Aerodyn. 2020, 197, 104059. [CrossRef]

10. Li, L.; Chan, P.W. Numerical simulation study of the effect of buildings and complex terrain on the low-level winds at an airport in typhoon situation. Meteorol. Z. 2012, 21, 183-192. [CrossRef]

11. Safaei Pirooz, A.A.; Li, Y.F.; Flay, R.G.J. Numerical and wind-tunnel investigation of wind flow over urban areas. Struct. Eng. Soc. N. Z. (SESOC) J. 2020, 33, 47-56.

12. Miao, Y.; Liu, S.; Chen, B.; Zhang, B.; Wang, S.; Li, S. Simulating urban flow and dispersion in Beijing by coupling a CFD model with the WRF model. Adv. Atmos. Sci. 2013, 30, 1663-1678. [CrossRef]

13. Kwak, K.H.; Baik, J.J.; Ryu, Y.H.; Lee, S.H. Urban air quality simulation in a high-rise building area using a CFD model coupled with mesoscale meteorological and chemistry-transport models. Atmos. Environ. 2015, 100, 167-177. [CrossRef]

14. Blocken, B.; Janssen, W.D.; van Hooff, T. CFD simulation for pedestrian wind comfort and wind safety in urban areas: General decision framework and case study for the Eindhoven University campus. Environ. Modell. Softw. 2012, 30, 15-34. [CrossRef]

15. Montelpare, S.; D'Alessandro, V.; Lops, C.; Costanzo, E.; Ricci, R. A Mesoscale-Microscale approach for the energy analysis of buildings. J. Phys. Conf. Ser. 2019, 1224, 01202. [CrossRef]

16. Li, S.; Sun, X.; Zhang, R.; Zhang, C. A Feasibility Study of Simulating the Micro-Scale Wind Field for Wind Energy Applications by NWP/CFD Model with Improved Coupling Method and Data Assimilation. Energies 2019, 12, 2549. [CrossRef]

17. Temel, O.; Bricteux, L.; van Beeck, J. Coupled WRF-OpenFOAM study of wind flow over complex terrain. J. Wind Eng. Ind. Aerodyn. 2018, 174, 152-169. [CrossRef]

18. Rockel, B.; Will, A.; Hense, A. The regional climate model COSMO-CLM (CCLM). Meteorol. Z. 2008, 17, 347-348. [CrossRef]

19. Germano, N.; Lops, C.; Montelpare, S.; Camata, G.; Ricci, R. Determination of Wind Pattern Inside an Urban Area through a Mesoscale-Microscale Approach. Math. Modell. Eng. Probl. 2020, 7, 515-519. [CrossRef]

20. Grell, G.A.; Dudhia, J.; Stauffer, D. A description of the fifth-generation Penn State/NCAR Mesoscale Model (MM5). Univ. Corp. Atmos. Res. 1994. [CrossRef]

21. CD-Adapco, STAR-CCM+11.0 User Guide; CD-Adapco Inc.: Melville, NY, USA, 2016.

22. Tewari, M.; Kusaka, H.; Chen, F.; Coirier, W.J.; Kim, S.; Wyszogrodzki, A.A.; Warner, T.T. Impact of coupling a microscale computational fluid dynamics model with a mesoscale model on urban scale contaminant transport and dispersion. Atmos. Res. 2010, 96, 656-664. [CrossRef]

23. Abiven, C. Mesoscale \& CFD coupling for wind energy yield prediction. In European Wind Energy Conference and Exhibition (EWEC); WindEurope: Vienna, Austria, 2013; Volume 2, pp. 1322-1325.

24. Li, L.; Liu, Y.; Yang, Y.; Han, S. Short-term wind speed forecasting based on CFD pre-calculated flow fields. Zhongguo Dianji Gongcheng Xuebao/Proc. Chin. Soc. Electr. Eng. 2013, 33, 27-32.

25. Ke, S.; Dong, Y.; Zhu, R.; Wang, T. Wind-sand coupling movement induced by strong typhoon and its influences on aerodynamic force distribution of the wind turbine. Wind Struct. Int. J. 2020, 30, 433-450. [CrossRef]

26. Takemi, T.; Ito, R. Benefits of high-resolution downscaling experiments for assessing strong wind hazard at local scales in complex terrain: A case study of Typhoon Songda (2004). Prog. Earth Planet. Sci. 2020, 7, 4. [CrossRef]

27. Stuff. Auckland Harbour Bridge Chaos: Tipped Truck Causes Gridlock on Motorways. 2020. Available online: https://www. stuff.co.nz/national/300110727/auckland-harbour-bridge-chaos-tipped-truck-causes-gridlock-on-motorways (accessed on 26 April 2021).

28. Boutle, I.A.; Finnenkoetter, A.; Lock, A.P.; Wells, H. The London Model: Forecasting fog at 333 m resolution. Q. J. R. Meteorol. Soc. 2016, 142, 360-371. [CrossRef] 
29. Bush, M.; Allen, T.; Bain, C.; Boutle, I.; Edwards, J.; Finnenkoetter, A.; Franklin, C.; Hanley, K.; Lean, H.; Lock, A.; et al. The first Met Office Unified Model-JULES Regional Atmosphere and Land configuration, RAL1. Geosci. Model Dev. 2020, 13, 1999-2029. [CrossRef]

30. Vosper, S.; Carter, E.; Lean, H.; Lock, A.; Clark, P.; Webster, S. High resolution modelling of valley cold pools. Atmos. Sci. Let. 2013, 14, 193-199. [CrossRef]

31. Smith, D.K.E.; Renfew, I.A.; Dorling, S.R.; Price, J.D.; Boutle, I.A. Sub-km scale numerical weather prediction model simulations of radiation fog. Q. J. R. Meteorol. Soc. 2021, 147, 746-763. [CrossRef]

32. Walters, D.; Boutle, I.; Brooks, M.; Melvin, T.; Stratton, R.; Vosper, S.; Wells, H.; Williams, K.; Wood, A.N.; Bushell, A.; et al. The Met Office Unified Model Global Atmosphere 6.0/6.1 and JULES Global Land 6.0/6.1 configurations. Geosci. Model Dev. 2017, 10, 1487-1520. [CrossRef]

33. Richards, P.J.; Norris, S.E. Appropriate boundary conditions for a pressure driven boundary layer. J. Wind Eng. Ind. Aerodyn. 2015, 142, 43-52. [CrossRef]

34. Menter, F.R. Two-equation eddy-viscosity turbulence models for engineering applications. AIAA J. 1994, 32, 1598-1605. [CrossRef]

35. Menter, F.R.; Carregal Ferreira, J.; Esch, T.; Konno, B. The SST Turbulence Model with Improved Wall Treatment for Heat Transfer Predictions in Gas Turbines. In Proceedings of the International Gas Turbine Congress, Tokyo, Japan, 2-7 November 2003; Gas Turbine Society of Japan (GTSJ): Tokyo, Japan, 2003.

36. Menter, F.R. Review of the shear-stress transport turbulence model experience from an industrial perspective. Int. J. Comput. Fluid Dyn. 2009, 23, 305-316. [CrossRef]

37. AS/NZS 1170.2. Australia/New Zealand Standard, Structural Design Actions. Part 2: Wind Actions; Standards Australia International Ltd.: Sydney, Australia; Standards New Zealand: Wellington, New Zealand, 2011.

38. Wilcox, D.C. Turbulence Modeling for CFD, 1st ed.; DCW Industries: Cape Town, South Africa, 1993.

39. Launder, B.E.; Spalding, D.B. The numerical computation of turbulent flows. Comput. Methods Appl. Mech. Eng. 1974, 3, 269-289. [CrossRef]

40. Grotjans, H.; Menter, F.R. Wall Functions for General Application CFD Codes. In Proceedings of the Fourth European Computational Fluid Dynamics Conference, Chichester, Athens, 7-11 September 1998; John Wiley Sons: Hoboken, NJ, USA, 1998.

41. Safaei Pirooz, A.A.; Flay, R.G.J. Comparison of Speed-Up Over Hills Derived from Wind-Tunnel Experiments, Wind-Loading Standards, and Numerical Modelling. Boundary-Layer Meteorol. 2018, 168, 213-246. [CrossRef]

42. ANSYS, Inc. ANSYS CFX-Pre User's Guide; ANSYS, Inc.: Canonsburg, PA, USA, 2011.

43. Popiolek, Z. Estimation of Mean Speed and Standard Deviation from CFD Prediction. Archit. Civ. Eng. Environ. 2008, 1, 141-146.

44. Holmes, J.D. Wind Loading of Structures, 3rd ed.; Taylor \& Francis Group: Abingdon, UK, 2015.

45. Safaei Pirooz, A.A.; Flay, R.G.J.; Minola, L.; Azorin-Molina, C.; Chen, D. Effects of sensor response and moving average filter duration on maximum wind gust measurements. J. Wind Eng. Ind. Aerodyn. 2020, 206, 104354. [CrossRef]

46. Safaei Pirooz, A.A.; Flay, R.G.J. Effects of a Solid Tower and Urban Area on Measured Wind Data: Numerical and Wind-Tunnel Simulations. In Proceedings of the 15th International Conference on Wind Engineering, Beijing, China, 1-6 September 2019.

47. Coleman, S.A.; Baker, C.J. The Reduction of Accident Risk for High Sided Road Vehicles in Cross Winds. J. Wind Eng. Ind. Aerodyn. 1992, 41-44, 2685-2695. [CrossRef]

48. Dorigatti, F.; Sterling, M.; Rocchi, D.; Belloli, M.; Quinn, A.D.; Baker, C.J.; Ozkan, E. Wind tunnel measurements of crosswind loads on high sided vehicles over long span bridges. J. Wind Eng. Ind. Aerodyn. 2012, 107-108, 214-224. [CrossRef]

49. Snæbjörnsson, J.T.; Baker, C.J.; Sigbjörnsson, R. Probabilistic assessment of road vehicle safety in windy environments. J. Wind Eng. Ind. Aerodyn. 2007, 95, 1445-1462. [CrossRef]

50. Hemingway, R.; Robbins, J. Developing a hazard-impact model to support impact-based forecasts and warnings: The Vehicle OverTurning (VOT) Model. Meteorol. Appl. 2019, 27, e1819. [CrossRef] 